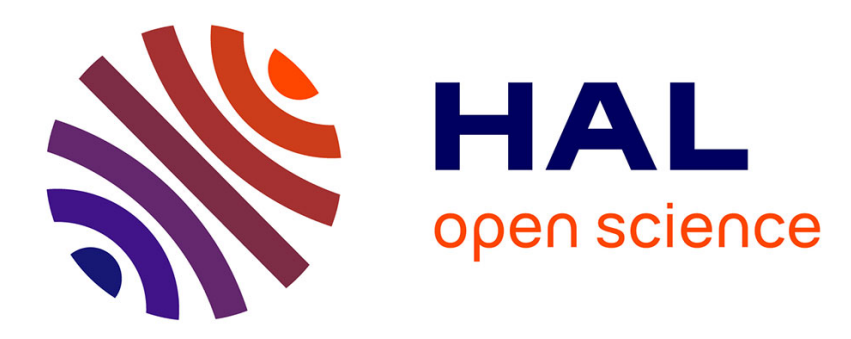

\title{
The Provision of Lighthouses Services: a Political Economy Perspective
}

Laurent Carnis

\section{To cite this version:}

Laurent Carnis. The Provision of Lighthouses Services: a Political Economy Perspective. Public Choice, 2013, 157 (1-2), pp 51-56. 10.1007/s11127-012-9951-y . hal-00868849

\section{HAL Id: hal-00868849 \\ https://hal.science/hal-00868849}

Submitted on 2 Oct 2013

HAL is a multi-disciplinary open access archive for the deposit and dissemination of scientific research documents, whether they are published or not. The documents may come from teaching and research institutions in France or abroad, or from public or private research centers.
L'archive ouverte pluridisciplinaire HAL, est destinée au dépôt et à la diffusion de documents scientifiques de niveau recherche, publiés ou non, émanant des établissements d'enseignement et de recherche français ou étrangers, des laboratoires publics ou privés. 


\section{The Political Economy of Lighthouses Laurent CARNIS}

Carnis Laurent (2003) "The Provision of Lighthouses Services: a Political Economy Perspective", Public Choice, Vol. 157(1): 51-56.

http://www.springerlink.com/openurl.asp?genre=article\&id=doi:10.1007/s11127-0129951-y (Acceptation et mise en ligne de l'article en 2012). 


\section{Introduction}

2011 was the 200th anniversary of the establishment of the Lighthouse Commission in France. With the commission was born a national navigation security policy. One outcome of this administrative decision was the suppression of lighting dues. The issue, then, was to produce a "free public good", a policy that led to a break in the management and the economy of coastal lighting (Guigueno $2011 \mathrm{p}$. 8). While for many commentators lighthouse management can be a matter purely and solely of public production, Coase's paper serves to demonstrate that an alternative does exist (Coase 1974).

His article convincingly demonstrates that economists' use of lighthouses as an obvious example of a public good is less certain than it might seem. The Trinity House case shows that private production in this field is in fact possible. It references the situation that came into being in Great Britain in the 16th century, when the construction and management of lighthouse services involved associations with private entrepreneurs. Coase's article has been roundly criticised, with certain commentators concluding that the production quoted is far from strictly private and that the de facto association of private and public led to more problems than benefits, with the collapse of the institutional arrangement providing the final proof.

The Coase debate reflects discussions going well beyond the lighthouse issue: the respective definitions of private and public production, the role of the State, and the institutional possibilities for producing a public good. In fact Coase's paper highlights the possibility of an economic analysis of lighthouses, maintaining as it does that their building and management should not be in the hands solely of engineers, technicians and bureaucrats.

While it calls for an investigation of the economy of lighthouses as such, Coase's paper also stresses the need for more specific attention to the institutional framework and production conditions for lighthouse services. Its overt intention is a political and economic approach to the subject which leaves ample scope for consideration of institutional design and the associated political issues.

In its first part my article shows that it can be readily agreed that the Trinity House case cannot be described in terms of strictly private production, government involvement and control being too significant for this to be a free market example. Nonetheless, Coase's article demonstrates convincingly that private entrepreneurs were of definite benefit in providing this kind of service and ensuring safety for seaborne traffic - and all the more so in that subsequent public sector production was unsatisfactory. What emerges from discussions of the Coase article is the possibility of private production of a public good - voluntary cooperation between users, building of private lighthouses even if the Trinity House example as such does not validate the hypothesis. This point of view is backed up by the possibility that public goods can be produced using private sector funds. 
Nonetheless, the evolution of the British system demonstrates the importance of the institutional framework in the production of such goods. The government is a core part of the institutional arrangement and can influence and shape it. The aim of the second part of this paper is to emphasise the political importance of lighthouses and related economic issues if the government is to find a means of extracting additional revenue at the population's expense. The thesis I put forward here is that the Trinity House system is explicable in terms of economic and political considerations, and notably rent seeking. Its collapse, far from proving that private production is unfeasible, points up changes in political coalitions, a political shift - the implementation of an ideology hostile to private property and previous institutional arrangements - and a new distribution of income (redistribution of rent).

\section{The lighthouse as an emblematic example of private production of public goods}

\subsection{Did private production of lighthouse services actually take place?}

Coase's article "The Lighthouse in Economics" is not only a major contribution to economic analysis of lighthouses as such, but a significant addition to economic analysis in general. Above all it reverses standard analyses by suggesting that private production of a public good is feasible and by illustrating its hypothesis with a symbolically empirical case study, that of Trinity House. The symbolism is all the more crucial in that in the literature and in education the lighthouse example is traditionally cited to justify the market's inability to handle production of a public good. In short, Coase's study challenges what was considered one of the foundations of economic analysis as commonly accepted within the profession.

\footnotetext{
"The early history shows that, contrary to the belief of many economists, a lighthouse service can be provided by private enterprises" (Coase 1974 p. 375).
}

The article was first critiqued in detail by Van Zandt (1993), who set out to invalidate Coase's theory on the grounds that public involvement was much more substantial than Coase admits: government intervention, says Van Zandt, was essential to production of lighthouse services, and this makes the example ill-suited to the illustration of private production of public goods.

A similar line of attack was taken by Bertrand (2006), who asserts that the historical illustration put forward by Coase is of a production system mixing the public and private sectors $-\mathrm{a}$ mix which, Bertrand says, was responsible for its unsatisfactory functioning. The private entrepreneurs running the lighthouses are described as primarily driven by the profit motive and are presented as incompetents and eccentrics (Bertrand 2006, p. 398). However, the most pertinent 
criticism, it seems to me, is the methodological one, which suggests a tendentious reading of the situation on Coase's part.

\footnotetext{
"Our analysis illustrates the difficulty of empirical studies: their interpretation depends on the choice of described elements" (Ibid. p. 390).
}

Bertrand's argument, though, collapses with his own strictures on Coase's method. His understanding of the Trinity House case is just as open to criticism in that it relies on a specific interpretation of the historical facts and a predetermined but not explicitly defined interpretative framework. Why, indeed, should profit-seeking be unacceptable in the domain of lighthouse services production?

The arguments put forward by Barnett and Block (2007) likewise set out to negate Coase's thesis on the grounds that the historical example in no way illustrates a strictly private production. Even so, the authors do not conclude that private production of lighthouse services is an impossibility, defining its modalities and finding an example in the work of Van Zandt.

Coase's critics also differ as to what constitutes private production of lighthouse services, the role of the state and the conclusions to be drawn from Coase's example (Block and Barnett II 2009; Bertrand 2009). The difference here is between those who maintain that private production of lighthouse services is possible even when Coase's empirical example is invalid, and those for whom his example in no way demonstrates the ability of the private sector to handle private production of lighthouse services, with the collapse of the Trinity House system being cited as definitive proof.

\subsection{Some lessons on the production of lighthouse services}

While avoiding both a detailed exposition of Coase's ideas and the risk of interpretative overkill, it should be said that the example he uses is not one of a strictly private production of lighthouse services. In this respect the description of a mixed-economy production - and not only in terms of its financing - is accurate. What is involved is a combination of private activities and public intervention. Coase does not, in fact, claim that production here is strictly private (Coase 1974, p. 375). On the contrary, he emphasises the diversity of the institutional methods for the production of these services (Ibid. p. 362) and proposes a study of one of them so as to demonstrate that private incapacity is not necessarily the case. In fact the Trinity House case illustrates a possible involvement of the private sector in lighthouse management and service production. Coase also demonstrates that public production is not necessarily a panacea and can indeed be a source of inefficiency (Coase 1974, p. 364). 
Thus Coase is very much aware of the role of the state in the production of such services as the granting of the administrative authorisation (the "patent"), calculation of dues and assistance with their collection (Ibid. p. 364). To say otherwise would be to judge him hastily and unfairly. A major question that has to be put here is whether or not public intervention in this specific example enables private production and if private production is cannot take place without it. If the latter were true, private production in the absence of state intervention would have been impossible and Coase's argument would collapse.

An alternative lies in the fact that production of lighthouse services is a strategic, tradefacilitating activity and thus is an industry subject to regulation and intervention (Pöder 2010). In this case the association of private actors with the government reflects only a structuring of political power and a means of obtaining revenue for the government. Thus private production of a public lighthouse services good would remain possible and could not be excluded. There is historical support for this point of view (Taylor 2001; Van Zandt 1993).

Debate on Coase's article also underscores one essential aspect of what must be considered public production and private production outside the sole domain of lighthouses. Given the omnipresence of government intervention in economic affairs and the economy generally (Mises 1998), today's production of goods and services takes place in the context of a mixed economy (Ikeda 1997). This hybrid situation does not, however, invalidate the capacity of private production. If such were the case for lighthouses, the same situation would logically have to be seen as applying to many other goods and services. In fact, it cannot be deduced from mixed-economy production that private actors are incapable of finding solutions to their problems, any more than such production expresses a free-market response (Barnett and Block 2007, p.724). Were the contrary true, production of certain goods and services could not take place, or would take quite a different form. However it remains difficult here to define private production in greater detail, as this would require a counterfactual comparison of what might have happened and what actually did happen. This would mean looking for armchair economist solutions of a purely theoretical kind or resorting to natural experiments (Diamond and Robinson 2010).

Another point that arises here is the fact that the private/public association might not be efficient and could lead to difficulties (Bertrand 2006, p.390). While this mixed economy system might be seen as the worst solution, nothing about it indicates that the difficulties necessarily stem from intervention by private sector actors. On the contrary, what is needed is an examination of the allocations of resources within each sphere - private and public - and a comparison of their respective performances (Carnis 2010).

There remains the fact that according to Coase's historical example production would have probably taken place without government intervention because fishermen and communities wanted 
the infrastructures needed to protect them from the losses entailed by shipwrecks and beachings (Taylor 1993, p. 49). It can also be reasonably asserted that the collection of payments and the financing and evolution of the system would have taken another form than the system adopted by Trinity House in association with the government. And it remains the case that non-coercive associations of entrepreneurs - probably with solid community backing - would have enabled a partial response to the challenge of private production of a public good.

\subsection{Theoretical lessons and responses}

Part of the debate lies in the description of the good in question. Are we faced with a "free riding" problem here, with the fishermen not contributing to lighthouse production and upkeep thus calling into question the production of services achieved by the others? Is the issue that of the limitations of production of public or club goods? Absence or inadequacy of cooperation between individuals would result in non-production of a public good. Is the question one of managing the production of positive external effects? The production of lighthouses would be insufficient to the extent that income would be lower than that required for optimal production.

As it happens, there is a substantial literature on these issues and ways of coping with the associated challenges. Buchanan's work on club goods highlights the importance of institutional arrangements that favour cooperation by making it possible to exclude non-contributors.

"... the theory of clubs is, in one sense, a theory of optimal exclusion, as well one of inclusion;"

(Buchanan 1965, p. 13)

"This suggests that one important means of reducing the costs of securing voluntary co-operative agreements is that of allowing for more flexible property arrangements and for excluding devices." (Ibid., p. 14)

Here private production of lighthouse services can find a solution in mechanisms for exclusion from the port, notably for local fishermen. This solution is especially appropriate for lighthouses used to signal local dangers, but it does nothing about the problem of the contribution from merchant shipping. Access to trading ports can then be seen as a by-product - a selective incentive - enabling resolution of the collective action problem (Olson 1987: 162-163). The shipper has not only to keep navigation costs down, he must also ensure avoidance of shipwrecks and beachings. The merchandise being transported has a commercial value and can bring a profit once successfully delivered to its destination. For Coase fishermen's readiness to contribute voluntarily to the production of lighthouse services can be understood as the outcome of an economic calculation: the non-production of lighthouse services, with the attendant risk of shipwrecks, could ultimately be more costly than a contribution to the building of lighthouses (Coase 1974, p. 364). Here the 
production of lighthouse services has to be incorporated into a broader view of purchases of navigation aids. Moreover, the services produced by lighthouses enable better transport of merchandise at a lower cost - reduction of shipwreck insurance payments, all other factors being equal - and allows for enhancement and economic development of the trading activities associated with the port.

The issues involved in private production of public goods and aid from local government were also part of the construction of the first toll roads (Klein and Fielding 1992). While Block (1983) provided a convincing response to the possibility of private production from a theoretical point of view, the empirical evidence offered by Klein and Fielding tends to demonstrate the ability of private entrepreneurs to come up with local solutions to production of public goods. Collective pressure, moral obligation and incentives for the development of these infrastructures have brought about private production later aided by government action in facilitating tollbooth payment (Ibid.: 330 and ff; Klein 1990, p. 802). The same argument is put forward by Taylor regarding private production of lighthouse services:

\footnotetext{
"While they did not have the support of the government to exclude free riders, they could call on a range of non-legal social and religious sanctions to support their work. Particularly with respect to local lights, the social pressure to contribute to lights intended to protect the lives and livelihoods and friends must have been great." (Taylor 1993, p. 61).
}

Private production of a localised public good would seem to constitute a solution to the problem of coordination between individuals and collective action. Ostrom's work on water management, irrigation problems and forest supervision offer a degree of support for this solution (Ostrom 2006 (1990)), as does other work with a similar emphasis (Anderson and Hill 2004). Nonetheless extraterritoriality does not seem to represent an insurmountable problem, as demonstrated by the lex mercatoria governing merchant shipping (Leeson 2008). Due regard for trade contracts remains possible even in the absence of state intervention.

At the same time production of lighthouse services raises two distinct issues: the ability to prevent consumption by a third party who has made no contribution to production; and joint consumption of the same production. Here we find the two features of a public good said to be illustrated by lighthouse-produced services.

As Snidal emphasises, a certain conceptual confusion prevails regarding the matter of public goods (Snidal 1979). There is a continuum for the joint consumption (non-rivalry) and non-exclusion aspects, while for Snidal there are, in fact, degrees of rivalry and excludability which depend on the 
characteristics of the good in question, the available technology and the political choices. There are no insurmountable problems here.

For him these different dimensions influence both the production costs of lighthouse services and the degree of rivalry and excludability (Ibid. p. 542-43). Consequently certain public goods are only public to the extent that it has been politically decided that they are.

\footnotetext{
"The political analysis of public goods problems is most appropriately viewed not as an analysis of the exchange of goods but as an analysis of authority between actors. The setting up of organizations or groups capable of imposing and enforcing property rights and collecting payments for centrally provided services is crucial to understanding how public goods (or, more correctly, quasi-public goods) are provided." (Snidal 1979, p. 564)
}

Current available technology - radio-navigation systems - enables identification of ships using lighthouse services or navigation aids, together with the ensuring of payment. In short, today's technology has solved the problem of the public good (Foldvary 2003), but lighthouse services still remain a public production which has to come to terms with problems of financing. Moreover, the great majority of lighthouses are no longer used for navigation purposes and have been turned into museums. In this latter case the service produced is competing and allows for exclusion; and yet production remains public, which brings us back to the argument put forward by Snidal and Buchanan: the political and institutional dimension remains crucial to an understanding of the status of a good. This is the interpretative framework which will be applied here to the debate on lighthouse services production in the case of Trinity House.

\section{Production of lighthouse services as political issues and rent seeking}

\subsection{Political issues linked to production of lighthouse services}

Van Zandt's approach opens up an interesting interpretative avenue for production of lighthouse services. "What is important," he says, "is to understand the types of governmental involvement in the provision of specific goods and services" (Van Zandt 1993, p. 48). Van Zandt sees the government as a supplier of institutional arrangements enabling reduction of the cost of social management of production of goods and services (Ibid. p.56). In this context different institutional arrangements for lighthouse production are possible according to available technology. Authors refer here to a publicprivate continuum (Van Zandt 1993; Pöder 2010). In a reinterpretation of Van Zandt's ideas, the government can make possible - but also impossible - private production of a public good. It can be 
readily understood that if the government decides to make exclusion of a good or a service impossible (independently of whether or not this is technically feasible), it will influence productive modalities, even if public production is involved. Consequently it is no longer a matter of understanding whether private production of lighthouses services is possible, but of understanding why the government has left the private sector the possibility of intervention in this sector. The author's reply is relatively clear in that what is at stake is a reduction of administrative management costs (Ibid. p. 56). Put another way, the institutional arrangement enables generation of a surplus that can be appropriated by the actors concerned. To a certain extent intervention of private entrepreneurs in production of lighthouse services can be interpreted as a productive outsourcing phenomenon which avoids capital outgoings while still ensuring revenue.

The significance of state intervention lies in the fact that the lighthouse must be seen as a political object. The first lighthouses served to mark entry into a sovereign territory (Van Zandt 1993, p. 58). Whether run by a centralised state or local governments, they were designed as monopolies tolerating no competition (Ibid. p. 64). They were means of generating not only direct income, but also revenue from the economic activity of ports on behalf of governments (taxes on products) (Pöder 2010, p. 329). Maritime commerce and the development of commercial fleets brought additional fiscal income via increased trade.

In stressing the possibility of private production of lighthouse services, Coase's article focused debate on the characteristics of the private sector and its modalities of intervention, while de-emphasising the strictly political and institutional issues involved. A reading of his contribution on the British lighthouse system (from the 16th century onwards) is highly instructive in this respect.

Firstly, the entry of lighthouses into the market required administrative authorisation from the government; this meant that the market was not free but, on the contrary, subject to controls and regulations. In addition, government agents played a vital role in the collection of dues, with coercion replacing voluntary contributions, social pressure and commercial contracts. Moreover, as the authorities laid down the amount of the payment, it was no longer a matter of a market-based price adjustable to market conditions (Van Zandt 1993, p.69). There also existed a group of boards shaping and regulating these productive activities.

The import of politics is even clearer in the case of the development of the lighthouse system in France, with economic logic vanishing under the weight of purely political considerations. In France the deliberate decision by the state to establish a rational network of lighthouses was a means of "asserting control of the sea and the coastline" (Guigueno 2007, p. 35). Expansion of the lighthouse system was based on an alliance between engineers (marshalling of scientific skills), improvements in building and lighting technology, and the state (Guigueno 2004, p. 26). The organisation of the lighting of the French coast aimed at even distribution, free service (at least for 
the user, since the state paid) and fully professional civil service status for lighthouse keepers - there were no entrepreneurs involved, as in the example considered by Coase.

\subsection{Regulation of lighthouse services as rent seeking}

The preceding section has demonstrated that the lighthouse represents a source of government revenue. Taylor mentions that the right to build and manage lighthouse services is acquired by payment of an annual rent:

"First, it granted to the entrepreneur the exclusive right for a term of years to build and maintain a lighthouse for a specific area in exchange for a fixed annual rent." (Taylor 1993, p. 65)

In fact the payment of this rent guaranteed the establishment of a monopoly situation of production of safety services, and so can be seen as a kind of subsidy for production. Production in this instance is undertaken by private entrepreneurs in a context of delegation or subcontracting of production by the state.

\footnotetext{
$"$...he need not worry about encroachment from competitors. Finally, his collection of revenues got a substantial subsidy from the state because of its readiness to use force to extract light dues from recalcitrant mariners." (Taylor 1993, p. 69)
}

This close relationship between entrepreneurs and the government results in a de facto political alliance, with lighthouse managers organising politically to defend their monopoly rent. Taylor also suggests in a little-cited footnote that lighthouse managers had formed a small but influential group within parliament (Taylor 1993, note 31 p. 57).

In this context the government-entrepreneur coalition existed to collect and share a rent related to a monopoly of lighthouse services production (Coase 1974, p.368). Denunciation of high light dues was in fact only the other side of a monopoly-protection coin; in a situation like this we can hardly speak of private production inefficiency.

Centralisation of the management of Trinity House private lighthouses amounted in fact to nationalisation or a consolidation of the monopoly rent for the sole benefit of the government, and redistribution of a part of the rent among other population groups: mariners and merchants. The gradual change in modalities of financing, from a system of dues to collective financing via a tax, shifted the load to the population as a whole. This went hand in hand with the growth of a state bureaucracy, and this leads Coase to say that the new administrative arrangement was perhaps inappropriate (Coase 1974, p. 374). 
Criticism of involvement by private entrepreneurs in the management of lighthouses must also be seen in the light of activity by pressure groups which gradually convinced the authorities that this institutional arrangement was harmful to trade and thus to the revenue to be drawn from it.

This struggle over rent became a focus for political self-interest which resorted to the notions of defence of the public interest and critique of private property for which Hume was the standardbearer (Taylor 2001, pp. 759-60). At the same time there was less criticism of state intervention in the economy than of certain monarchical practices involving the granting of monopolies to certain parties (Ibid. p. 761). Management of lighthouses in Estonia by the local nobility also reflected this policy of the granting of privileges (Pöder 2010, p. 331).

In fact, as Taylor convincingly demonstrates, the policy of nationalisation and hostility to private property reflected a new ideological orientation. Private property was no longer considered an absolute, and expropriation was justified in that it could serve the public interest without this interest being clearly defined (Taylor 2001, p. 751). In this respect the institutional evolution of production of lighthouse services reflected a generalised movement of intervention in the economy and redistribution of property rights. Moreover, the lighthouse case was the focus of a specific coalition between those who benefited from the reduction in lighting rights and the gradual shift to collective financing on the one hand, and those who presented the situation as an example of the struggle against monopolies and private property on the other.

A long quotation from Taylor is relevant here:

\footnotetext{
"The advocates of lighthouse reform were thus not merely attacking corruption, they were attacking the very existence of private property in a public service." (Taylor 2001, p.764)

"Private ownership of lighthouses, though tainted with old corruption, was not criticized solely because it had arisen through government patronage: it was attacked more fundamentally because private property in lighthouses was held to be morally wrong and antithetical to the interests of society. The morality of reform was expressed in terms of the 'public' interest. The definition of this public interest was crucial to the success of lighthouse reform." (Ibid. p. 762)
}

In addition to the transfer of revenue from lighthouse owners to mariners and merchants, what was also emerging was an ideology thinking in terms of the income of a nation and based on a holistic conception of society. Seen thus, the interests of lighthouse owners were a waste of public resources.

\footnotetext{
"Reform of this system was therefore in the public interest as it would redistribute economic resources from lighthouse owners and pensioners to shipowners, and by implication to the public as whole." (Ibid. p.764)
} 


\section{Conclusion}

Coase's article on the possibility of private production of lighthouse services highlights the fact that commonplace notions can sometimes conceal much more complex realities. Private production of such services is not impossible and the existence of alternative institutional arrangements makes it clear that there are more ways than one of providing them.

Did private production of lighthouse services actually happen? Coase's critics are unanimous in stating that his example cannot be considered as one of purely private production; but without going back over what is covered by the concepts of private and public property, the institutional arrangement Coase's example refers to does raise the issue of the economic role of the state and its modalities of intervention.

A substantial literature exists regarding the possibilities of private production of public goods. The case of Trinity House and its nationalisation in no way demonstrate the impossibility of private production, but it does foreground the importance of the institutional design controlled by the government.

This paper proposes another interpretative approach by suggesting that the lighthouse is an economic asset subject to political appropriation. Seen in this light, the institutional evolution illustrated by the English example points up the political byplay relating to monopoly rent seeking, the role of private property and the ideology that shapes state intervention. Economic analysis of lighthouses cannot, then, be undertaken without being approached in terms of economic policy. 
Anderson Terry L. and Peter J. Hill. (2004). The Not So Wild, Wild West: Property Rights on the Frontier, Stanford Economics and Finance.

Barnett William and Walter Block. (2007). "Coase and Van Zandt on Lighthouses", Public Finance Review, (35)6:710-733.

Bertrand Elodie. (2009). "Empirical Investigations and Their Normative Interpretations: A Reply to Barnett and Block", Public Choice, (140)1-2: 15-20.

Bertrand Elodie. (2006). "The Coasean Analysis of Lighthouse Financing: Myths and Realities", Cambridge Journal of Economics, (30)4: 389-402.

Block Walter. (1983), "Public Goods and Externalities: The Case of Roads", The Journal of Libertarian Studies, (VII)1: 1-34.

Block Walter and William Barnett. (2007). "Coase and Bertrand on Lighthouses", Public Choice, (140)1-2: 1-13.

Buchanan James M. (1965). "An Economic Theory of Clubs", Economica, (32)125: 1-14.

Carnis Laurent A. H. (2010), "New Perspectives on the Economic Approach to Bureaucracy", The Quarterly Journal of Austrian Economics, (13)2: 53-78.

Coase Ronald H. (1974). "The Lighthouse in Economics", Journal of Law and Economics, (17)2: 357376.

Diamond Jared and James A. Robinson (2010), Natural Experiments of History, Belknap Harvard.

Foldvary Fred (2003), "The Lighthouse as a Private-Sector Collective Good" In Fred E. Foldvary and Daniel B. Klein, eds., The Half-Life of Policy Rationales: How New Technology Affects Old Policy Issues, New York University Press, New York, p. 38-46.

Guigueno Vincent (2011). "La commission des phares (1811-1825), naissance d'une politique nationale de sécurité de la navigation ", Revue du Comité d'Histoire du ministère de l'Ecologie, du Développement Durable, des Transports et du Logement, Extrait n¹0, pp. 6-19.

Guigueno Vincent (2004). « La signalisation maritime en France: un projet poly - technique au début du XIXème siècle ", Bulletin de la SABIX, (35): 26-31.

Guigueno Vincent (2001). "L'Europe des Lumières. Organisation et technique de signalisation maritime au XIXe siècle », Histoire et Sociétés, (21): 30-42.

Ikeda Sanford. (1997). Dynamics of the Mixed Economy, Toward a Theory of Interventionism, Foundations of the Market Economy, Routledge.

Klein Daniel B. (1990). "The Voluntary Provision of Public Goods? The Turnpike Companies of Early America", Economic Inquiry, (XXVIII): 788-812. 
Klein Daniel B. and Gordon J. Fielding (1992), "Private Toll Roads: Learning from the $19^{\text {th }}$ Century", Transportation Quarterly, (46)3: 321-341.

Leeson Peter T. (2008). "Do Markets Need Government?" in Stephen F. Copp (ed.) The Legal Foundations of Free Markets, p. 42-83, Institute of Economic Affairs, London.

Mises (von) Ludwig. (1998). Interventionism, An Economic Analysis, Foundation for Economic Education.

Olson Mancur (1987), Logique de l'action collective, Presses Universitaire de France.

Ostrom Elinor (2006 [1990]), Governing of the Commons, The Evolution of Institutions for Collective Action, Political Economy of Institutions and Decisions, Cambridge University Press.

Pöder Kaire. (2010). "The Lighthouse in Estonia: The Provision Mechanism of "Public Goods"', Discussions on Estonia Economic Policy, XVIII, Berlin-Tallin.

Snidal Duncan (1979), "Public Goods, Property Rights, and Political Organizations", International Studies Quarterly, (23)4: 532-566.

Taylor James. (2001). "Private Property, Public Interest, and the Role of the State in NineteenthCentury Britain: The Case of the Lighthouses", The Historical Journal, (44)3: 749-771.

Van Zandt David E. (1993). "The Lessons of the Lighthouse: "Government" or "Private" Provision of Goods", The Journal of Legal Studies, (22)1: 47-72. 